Agro-Science Journal of Tropical Agriculture, Food, Environment and Extension Volume 8 Number 1 January 2009 pn. 20-23

ISSN 1119-7455

\title{
EFFECTS OF DIFFERENT LEVELS OF DECOMPOSED POULTRY MANURE ON YIELD OF CABBAGE (Brassica oleraceae L.) AT ANSE BOILEAU, SEYCHELLES
}

\author{
Ijoyah, M.O. ${ }^{1}$ and Sophie, V.L. ${ }^{2}$ \\ ${ }^{1}$.Department of Crop Production, University of Agriculture, P.M.B. 2373, Makurdi, Benue State, \\ Nigeria \\ ${ }^{2}$.Vegetable Evaluation and Research Station, Anse Boileau, Seychelles
}

\begin{abstract}
Field experiments were conducted between April and September, 2003 and 2004 at the Vegetable Evaluation and Research Station, Anse Boileau, Seychelles to assess the effects of different levels of decomposed poultry manure and to determine the optimal rate that would maximize cabbage yield under Seychelles conditions. The treatment consists of five levels of decomposed poultry manure (DPM) at 0, 10, 20, 30 and 40 t/ha. It was replicated four times in a randomized complete block design. Results of the study showed that all DPM treatments significantly improved head length, head width, head weight per plant and yield than the 0 t/ha DPM, however the best yield was obtained from the 30 t/ha DPM. The application of 30 t/ha DPM significantly $(P \leq 0.05)$ increased cabbage yield by $31.7 \%$ and $26.4 \%$ in the year 2003 and 2004 respectively compared to the 0 t/ha DPM treatment. The application of 30 t/ha DPM was therefore recommended.
\end{abstract}

Keywords: Manure application, Cabbage, Yield response.

\section{NTRODUCTION}

Cabbage (Brassica oleraceae L.) belongs to the Brassicaceae family and is a cool season crop (Best, 2000). It is consumed raw or cooked with other vegetables and mostly grown as a commercial crop. It contains $93 \mathrm{ml}$ water, $1.5 \mathrm{~g}$ protein, $0.2 \mathrm{~g}$ fat, $4 \mathrm{~g}$ carbohydrate, $40 \mathrm{mg}$ calcium and $0.5 \mathrm{~g}$ iron/100 g sample (Moamogwe, 1995).

In Seychelles, there is an increasing demand for the cultivation of cabbage to meet the needs of the urban markets. Cabbage is one of the priority vegetable crops in the diet of the Seychelles people (Grubben, 1997).

Poultry manure, an efficient organic fertilizer is readily available in the Seychelles, in sufficient amounts and it is an important source of plant nutrients (Reddy and Reddi, 1995). In addition to releasing nutrients, also improves the physical properties of soil. It has been reported that $30 \%$ of nitrogen from poultry litter is in urea or ammonium form and is hence readily available (Sunassee, 2001). Its average primary nutrient content is $3.03 \% \mathrm{~N}$, $2.63 \% \mathrm{P}_{2} \mathrm{O}_{5}$ and $1.4 \% \mathrm{~K}_{2} \mathrm{O}$ (Reddy and Reddi, 1995).

Yield response of leafy vegetable crop such as lettuce to different levels of poultry manure application has been investigated by (Cesalis, 2002), in which he reported that manure be applied at the rate of $20 \mathrm{t} / \mathrm{ha}$. Similarly, Sunassee (2001) in his research investigation on the use of poultry litter for vegetable production in Mauritius advised that the manure be applied at a rate of $15 \mathrm{t} / \mathrm{ha}$ for high yields.

Seychelles has a varied environmental condition and therefore optimal application levels of poultry manure could differ for specific crops. This study was therefore designed to evaluate the yield response of cabbage to different levels of poultry manure with the objective of determining the optimal rate that would maximize cabbage yield under Seychelles conditions

\section{MATERIALS AND METHODS}

Field trials were conducted between April and September, 2003 and 2004 at the Vegetable Evaluation and Research Station, Anse Boileau, Seychelles, which lies between longitude $7^{0} 26^{\prime}$ and $7^{0} 53^{\prime} \mathrm{E}$ and latitude $5^{0} 17^{\prime}$ and $5^{0} 26^{\prime} \mathrm{N}$. The annual rainfall ranges from $300 \mathrm{~mm}-400 \mathrm{~mm}$. The experiment was sited on sandy soil to evaluate the effects of different levels of decomposed poultry manure on yield of cabbage. The variety of cabbage used was 'Spring Light'. It is popularly grown by 
farmers, both for home use and source of income. Seedlings were developed in the nursery in which watering, application of starter fertilizer Nitrophoska (NPK 12-12-10) at the rate of $100 \mathrm{~g}$ per plot area of $3.0 \mathrm{~m}^{2}$ was applied following recommendation by Ripjma (1991), while pesticide application with Nomolt (a.i. Teflubenzuron) at the rate of $7 \mathrm{ml}$ mixed with 151 of water was sprayed following recommendation by Valenzuela (2002). The field site was cleared and rotovated. The experimental area was $79.4 \mathrm{~m}^{2}$ while each plot area was $3.0 \mathrm{~m}^{2}$.

The decomposed poultry manure (DPM) constituted the treatment at five levels namely: $0 \mathrm{t} / \mathrm{ha}$, $10 \mathrm{t} / \mathrm{ha}, 20 \mathrm{t} / \mathrm{ha}, 30 \mathrm{t} / \mathrm{ha}$ and $40 \mathrm{t} / \mathrm{ha}$. The treatments were laid out in a randomized complete block design (RCBD) with four replications. Planting holes measuring $6.0 \mathrm{~cm}$ depth were dug at a spacing of 50 $\mathrm{cm} \times 50 \mathrm{~cm}$ between and within rows in each treatment plot. DPM at the different rates of $125 \mathrm{~g}$, $250 \mathrm{~g}, 375 \mathrm{~g}$ and $500 \mathrm{~g}$ (equivalent of $10 \mathrm{t} / \mathrm{ha}, 20$ $\mathrm{t} / \mathrm{ha}, 30 \mathrm{t} / \mathrm{ha}$ and $40 \mathrm{t} / \mathrm{ha}$ ) were applied in each hole a day before transplanting. Seedlings were transplanted in early June, four weeks after sowing (W.A.S) to each plot. Each plot consisted of two rows to which 12 plants per row were transplanted giving a total population of 24 plants per plot $(80,000$ plants per hectare equivalent).

Irrigation was applied using the drip system. Weeding was manually carried out by handpicking as the weeds appeared until harvest, while pests were controlled 6 weeks after transplanting by foliar spray with Nomolt at the rate of $12 \mathrm{ml}$ mixed with 301 of water (Valenzuela, 2002). Harvesting was done in early September when matured heads were produced.

Data taken included mean head length, mean head width, mean weight of non-wrapper leaves, mean head weight per plant and yield ( $t / h a)$. The data were statistically analyzed using the Analysis of Variance (ANOVA) while the Least Significant Difference (LSD) was used to separate treatment means following the method of Obi (1990).

\section{RESULTS AND DISCUSSION}

In Table 1, the meteorological information of the trial site from April to September 2003 and 2004 is given. The average monthly temperature over the years ranged from $22.2{ }^{\circ} \mathrm{C}$ to $29.2{ }^{\circ} \mathrm{C}$. This range was considered optimal for the growth and development of cabbage. This view was supported by Cooper (2000). He reported that optimal temperature range of $20-30{ }^{\circ} \mathrm{C}$ is ideal for cabbage.
In the months of May and June, the highest average monthly rainfall and highest number of rainy days were recorded. The highest average relative humidity of $85.3 \%$ and $85.5 \%$ were recorded for the month of June.

Total $\mathrm{N}$ value in the soil over the years was low $(0.06 \%$ and $0.09 \%)$. Similarly, the soil had a medium level of $\mathrm{P}\left(8.6 \mathrm{mg} / \mathrm{kg}^{-1}\right.$ and $\left.9.2 \mathrm{mg} / \mathrm{kg}^{-1}\right)$ with a corresponding low level of $\mathrm{K}(0.08 \%$ and $0.10 \%)$ for the years 2003 and 2004 respectively. Relatively moderate amounts of exchangeable bases ( $\mathrm{Ca}$ and $\mathrm{Mg}$ ) were present in all the soil units. Over the years, organic matter was low $(1.7 \%$ and $1.5 \%)$ while the $\mathrm{pH}$ in water was near neutral (Table 2).

All the four levels of DPM gave increased head length, head width, weight of non-wrapper leaves, head weight per plant and yield than the 0 t/ha DPM (Table 3). DPM rate at $30 \mathrm{t} / \mathrm{ha}$ gave the highest mean head length $(11.8 \mathrm{~cm}$ and $13.2 \mathrm{~cm})$ and head width $(12.9 \mathrm{~cm}$ and $13.4 \mathrm{~cm})$ for year 2003 and 2004 , respectively. This agreed with a similar work in Madagascar by Rajkomar (2002), where the highest head length and head width were obtained with the application of $30 \mathrm{t} / \mathrm{ha}$ DPM. However, the mean weight of non-wrapper leaves was not significantly different irrespective of the levels of DPM application.

The application of $30 \mathrm{t} / \mathrm{ha}$ DPM also gave the highest mean head weight per plant $(1.30 \mathrm{~kg}$ and 1.26 $\mathrm{kg}$ ) and yield of $35.6 \mathrm{t} / \mathrm{ha}$ and $34.8 \mathrm{t} / \mathrm{ha}$ respectively for year 2003 and 2004, respectively. These were significantly $(\mathrm{P}<0.05)$ higher than those obtained from other levels. This rate in the year 2003, significantly $(\mathrm{P}<0.05)$ increased mean head weight per plant and yield by $50.8 \%$ and $31.7 \%$ respectively compared to those obtained from $0 \mathrm{t} / \mathrm{ha}$. A similar trend was obtained in 2004, were the application of $30 \mathrm{t} / \mathrm{ha}$ DPM significantly increased mean head weight per plant and yield by $39.7 \%$ and $26.4 \%$, respectively, compared to those obtained from the plots with no application of DPM. This result, however do not agree with a similar investigation in Malaysia by Talekar (2000), who reported that the highest head weight per plant and best yield were obtained with the application of 20 t/ha of decomposed poultry manure. The difference in results could be attributed to varietal response to different environments of the two study locations and to the relatively low soil nutrient status of the study site in the Seychelles. 
Ijoyah, M.O. and Sophie, V.L.

Table 1: Meteorological information for Anse Boileau, Seychelles (April-September) 2003, 2004.

\begin{tabular}{|c|c|c|c|c|}
\hline \multirow[b]{3}{*}{2003} & \multirow{3}{*}{$\begin{array}{l}\text { Average monthly } \\
\text { Rainfall (mm) }\end{array}$} & \multicolumn{2}{|c|}{ Average monthly } & \multirow{2}{*}{$\begin{array}{l}\text { Average relative } \\
\text { humidity }(\%)\end{array}$} \\
\hline & & tempe & e $\left({ }^{0} \mathrm{C}\right)$ & \\
\hline & & Max. & Min. & \\
\hline April & $12.3(20)^{+}$ & 22.5 & 28.2 & 84.2 \\
\hline May & $142(22)$ & 292 & 232 & 841 \\
\hline June & $15.3(24)$ & 28.3 & 23.1 & 85.3 \\
\hline July & $4.0(11)$ & 28.4 & 22.8 & 80.1 \\
\hline August & $3.6(17)$ & 27.5 & 22.2 & 81.4 \\
\hline September & $3.4(15)$ & 26.6 & 22.6 & 81.6 \\
\hline \multicolumn{5}{|l|}{2004} \\
\hline April & $13.4(18)^{+}$ & 28.3 & 22.4 & 84.2 \\
\hline May & $15.1(20)$ & 28.2 & 22.5 & 84.0 \\
\hline June & $18.6(27)$ & 27.7 & 23.2 & 85.5 \\
\hline July & $9.6(14)$ & 27.5 & 22.3 & 82.1 \\
\hline August & $7.5(16)$ & 28.2 & 23.1 & 82.3 \\
\hline September & $7.3(14)$ & 27.4 & 23.4 & 82.4 \\
\hline
\end{tabular}

Values in parenthesis indicate number of rainy days.

Source: Vegetable Evaluation and Research Meteorological Station, Anse Boileau

Seychelles

Table 2: Physico-chemical properties of the soil of experimental site, 2003 and 2004.

\begin{tabular}{llll}
\hline Parameter & $\mathbf{2 0 0 3}$ & $\mathbf{2 0 0 4}$ & Method of analysis \\
\hline Organic matter & $1.7 \%$ & $1.5 \%$ & Walkley-Black method \\
Nitrogen & $0.06 \%$ & $0.09 \%$ & Kjeldahl method \\
$\mathrm{P}_{2} \mathrm{O}_{5}$ & $8.6 \mathrm{mg} / \mathrm{kg}^{-1}$ & $9.2 \mathrm{mg} / \mathrm{kg}^{-1}$ & Flame photometric method \\
$\mathrm{K}$ & $0.08 \%$ & $0.10 \%$ & Oxidation method \\
$\mathrm{Ca}$ & $2.04 \mathrm{meq} / 100 \%$ & $2.13 \mathrm{meq} / 100 \%$ & A.A.S. \\
$\mathrm{Mg}$ & $1.04 \mathrm{meq} / 100 \%$ & $2.01 \mathrm{meq} / 100 \%$ & A.A.S. \\
$\mathrm{pH}\left(\mathrm{H}_{2} \mathrm{O}\right)$ & 6.4 & 6.8 & pH meter \\
$\mathrm{pH}\left(\mathrm{Cacl}_{2}\right)$ & 5.3 & 5.7 & pH meter \\
\hline
\end{tabular}

Type of Soil: Sandy

Source: Soil Science Laboratory, Grand Anse, Mahe, Seychelles.

A.A.S.: Atomic Absorption Spectrophotometer

Table 3: Yield components of cabbage at the different levels of decomposed poultry manure for the year 2003 and 2004.

\begin{tabular}{|c|c|c|c|c|c|c|c|c|c|c|}
\hline \multirow[b]{2}{*}{ Treatments } & \multicolumn{2}{|c|}{$\begin{array}{l}\text { Mean head } \\
\text { length } \\
(\mathrm{cm})\end{array}$} & \multicolumn{2}{|c|}{$\begin{array}{l}\text { Mean head } \\
\text { width } \\
(\mathrm{cm})\end{array}$} & \multicolumn{2}{|c|}{$\begin{array}{l}\text { Mean weight of } \\
\text { non-wrapper leaves } \\
\text { (g) }\end{array}$} & \multicolumn{2}{|c|}{$\begin{array}{l}\text { Mean head } \\
\text { weight per plant } \\
\quad(\mathrm{kg})\end{array}$} & \multicolumn{2}{|c|}{$\begin{array}{l}\text { Yield } \\
(\mathbf{t} / \mathbf{h a})\end{array}$} \\
\hline & 2003 & 2004 & 2003 & 2004 & 2003 & 2004 & 2003 & 2004 & 2003 & 2004 \\
\hline $0 \mathrm{t} / \mathrm{ha}$ & 7.7 & 8.9 & 8.6 & 9.2 & 10.2 & 9.8 & 0.64 & 0.76 & 24.3 & 25.6 \\
\hline $10 \mathrm{t} / \mathrm{ha}$ & 10.4 & 11.3 & 11.2 & 12.7 & 10.5 & 10.9 & 0.95 & 0.94 & 29.4 & 29.8 \\
\hline $20 \mathrm{t} / \mathrm{ha}$ & 10.6 & 11.3 & 11.8 & 12.7 & 11.3 & 10.5 & 0.97 & 0.99 & 30.3 & 31.0 \\
\hline $30 \mathrm{t} / \mathrm{ha}$ & 11.8 & 13.2 & 12.9 & 13.4 & 11.6 & 12.4 & 1.30 & 1.26 & 35.6 & 34.8 \\
\hline $40 \mathrm{t} / \mathrm{ha}$ & 9.7 & 11.0 & 11.7 & 11.6 & 10.7 & 11.0 & 0.86 & 0.93 & 31.4 & 29.9 \\
\hline Means & 10.0 & 11.1 & 11.2 & 11.9 & 10.9 & 10.9 & 0.94 & 0.98 & 30.2 & 30.2 \\
\hline LSD0.05 & 2.4 & 4.1 & 3.7 & 3.4 & NS & 3.8 & 0.2 & 0.1 & 3.7 & 3.2 \\
\hline $\mathrm{CV}(\%)$ & 9.46 & 7.20 & 6.32 & 4.80 & 9.34 & 8.10 & 13.41 & 15.63 & 6.69 & 8.20 \\
\hline
\end{tabular}

NS: Not Significant 


\section{CONCLUSION}

From the results obtained, it can be concluded that the application of $30 \mathrm{t} / \mathrm{ha}$ of decomposed poultry manure is recommended. This application is associated with higher head length, head width, weight of nonwrapper leaves, head weight per plant and yield respectively. It is recommended that the experiment be conducted across different locations with varied ecology in Seychelles

\section{ACKNOWLEDGEMENTS}

We thank the Ministry of Environment and Natural Resources, Seychelles for the sponsorship of this study and the research technicians for their assistance in the field operations

\section{REFERENCES}

Best, K. (2000). Adaptation of Cabbage Varieties. ARP Training Reports. AVRDC-AFRICA Regional Programme, Arusha, Tanzania,p.10.

Cesalis, T. R. (2002). Yield Evaluation of Lettuce Varieties. Agricultural Technology Journal, 5: 20-24.

Cooper, S. S. (2000). Adaptation Trial on Heading Cabbage Cultivars in Rundu, Namibia. Namibia Agricultural Journal, 2 (1): 20 - 24.

Grubben, G.J.H. (1997). Tropical Vegetable and Their Genetic Resources. Royal Tropical Institute, Amsterdam, Netherland, p. 102.

Moamogwe, M. (1995). Adaptation Trial of Introduced Cabbage Cultivars. ARP Training Reports (19951997) AVRDC-AFRICA Regional Programme, Arusha, Tanzania, pp. 27-29.

Obi, I.U. (1990). Statistical Method of Detecting Differences Between Treatment Means. SNAAP Press (Nig.) Ltd, Enugu, Nigeria, pp. 1-14.

Rajkomar, I. (2002). Comparative Performance of Three Cabbage Varieties to Different Rates of Poultry Manure in Madagascar. Netherlands Journal of Agricultural Science, 41: 98-101.
Reddy, T. Y. and Reddi, G.H. (1995). Principles of Agronomy. $2^{\text {nd }}$ Edition, Kalyani Publishers. New Delhi, 110002, p.223.

Ripjma, J. (1991). FAO Fertilizer Recommendation. Extension Bulletin, 2: 10-12.

Sunassee,S. (2001). Use of Litter for Vegetable Production. AMAS 2001. Food and Agricultural Research Council, Reduit, Mauritius, pp. 259 263.

Talekar, N. S. (2000). Chinese Cabbage. Proceedings $1^{\text {st }}$ International Symposium on Cabbage. AVRDC, Shanhua, Tainan, Taiwan, pp. 67-69.

Valenzuela, H. (2002). Field Cabbage Guidelines for Hawaii: In Crop Production Guidelines. University of Hawaii, Cooperative Extension Bulletin, 4: 2-6. 